\title{
IS THE UNITED STATES SUPREME COURT AN UNDEMOCRATIC INSTITUTION? AN OUTSIDER'S PERSPECTIVE
}

\author{
LUKASZ MACHAJ*
}

\section{INTRODUCTION}

The accusation of activism has been leveled against the judicial branch of American government, and specifically against the United States Supreme Court, for many years. Many advocates of this criticism seem to explicitly or implicitly maintain - finding it repugnant - that the Court has followed and expanded upon the famous dictum of Chief Justice Earl Warren who claimed that the $8^{\text {th }}$ Amendment, because of its imprecise wording designating a non-static scope of validity, 'must draw its meaning from the evolving standards of decency that mark the progress of a maturing society' . While this statement initially referred only to the 'cruel and unusual punishment' phrase, I believe that the majority - if not all - of the critics of judicial activism would decisively assert that this quote rather accurately describes the basic trends of the Supreme Court's activity in many realms of Constitutional jurisprudence. Without a shadow of doubt they would all agree that the highest judicial tribunal in the land has often usurped the power of 'determining upon its own judgment whether particular legislation was desirable. The Court thus came virtually to exercise the functions of a 'superlegislature' [...] 'a third chamber in the United States'. According to supporters of this viewpoint, the Court has unjustifiably and unconstitutionally appointed itself 'the Supreme Censor of all legislation'2. It should be pointed out that the very term 'judicial activism' is equivocal. It may signify that judges and Justices go against either the explicit or implicit intent of the Founding Fathers or of the Constitution's Framers; that they

DOI : 10.2478/wrlae-2013-0025

* PhD; LLM; University of Wroclaw, Department of Political and Legal Doctrines;

1.machaj@prawo.uni.wroc.pl

${ }^{1}$ Trop v Dulles (1958) 356 US 86, 100-101.

2 Bernard Schwartz, The Supreme Court: Constitutional Revolution in Retrospect (Ronald Press 1957) 13-14. 
adopt a different construction of certain Constitutional clauses from the one originally accepted by people living during the times of the Constitutional Convention; that while solving hard cases they refuse to seriously take into account the wishes and demands of the majority of citizens; that they violate the rights of democratically-elected legislatures; that they base their decisions or verdicts upon evolving, enigmatic and unclear standards or tests (for instance, 'strict scrutiny', 'Lemon test' or 'O'Brien standard') which simply cannot be found in the plain text of the Constitution; that, making use of the fact that they wield truly extraordinary discretionary power, they attempt to translate their political preferences, animosities and idiosyncrasies into law; that they do not leave the settlement of political issues and disputes to political institutions. No matter which of the above-mentioned definitions is promulgated by a particular advocate of judicial restraint, they all seem to lead to a similar, inescapable conclusion: the U.S. Supreme Court (and all the other courts which follow its lead) is basically an undemocratic institution which subverts the will of the people, blithely tramples over people's right of self-rule, upsets the separation of powers as envisioned by Montesquieu ${ }^{3}$ and infringes upon the sacred principles of the American system of government.

This interpretative paradigm of the Supreme Court's role is loudly proclaimed by a great deal of the representatives of the political Right (particularly by those of the conservative persuasion). Robert Bork is of course its most recognized and vocal protagonist ${ }^{4}$ but by no means is he the only one. Let us take Lino A. Graglia's article as an instructive example of anti-activist fervor. He passionately argues that the U.S. Supreme Court perverts the function of law in a democratic society which is 'to express, cultivate, and enforce the values of the society as understood by the majority of its people'. According to Graglia, Justices consistently aim to overthrow and undermine these traditional values, depriving the American citizens of their most essential and cherished right of self-government. The Supreme Court has transformed the American political model into a tiny judicial oligarchy. Justices have arbitrarily appointed themselves 'the final lawmakers on any public policy issue that they choose to remove from the ordinary political process'. He goes as far as comparing the Supreme Court to the Grand Council of Ayatollahs in the Iranian political system. Graglia claims that Justices, being members of a 'cultural elite', have appropriated obviously in an unconstitutional manner - the role of 'the system's highest authority'. All of the above-mentioned factors inevitably lead to 'the extraordinary result in a supposedly democratic society': law becomes dependent on 'the values and preferences of a powerful nine-person elite', members of which do not hesitate to advance, per fas et nefas, their personal preferences by enacting them into law. While the Constitution precludes very few possible policy choices, the Justices impose far too many limitations, allegedly inferred from the Constitution, on the majority's will. Graglia

\footnotetext{
${ }^{3}$ It is worth reminding that the most influential proponent of the separation of powers concept, i.e. Charles de Secondat, Baron de Montesquieu perceived judges as "no more than the mouth which pronounces the words of the law, mere passive beings", Charles de Secondat, The Spirit of Laws (Batoche Books 2001) 180.

${ }^{4}$ Robert H Bork, The Tempting of America: Political Seduction of the Law (Free Press 1990); Robert H Bork id., Slouching Towards Gomorrah: Modern Liberalism and the American Decline (Regan Books 1996).
} 
concludes emphatically by saying that the American system is currently nothing more than 'a tyranny of minority'. Similar voices can - albeit admittedly more sporadically - be heard on the other end of political spectrum. Jamin B. Raskin's book provides us with an illustrative example . $^{6}$ The author strongly maintains that 'progressives have almost always had more cause than conservatives to assail the activism of the Supreme Court, which has been a force of ferocious political reaction for most of its existence'. The era of the Rehnquist Court was particularly troublesome to Raskin since during that time the unifying philosophy of the majority was not 'federalism, judicial restraint, strict textualism, or original intent but hostility to popular democracy'. Throughout its institutional history the Supreme Court often invalidated laws which did not violate explicit Constitutional provisions, overextending its authority beyond proper limits. It has been - as Raskin puts it - 'a historic disappointment' and sometimes even 'a nightmare' as far as neutrality, objectivity and 'refraining from aggressive judicial activism based on the political preferences of the justices' are concerned; its strictly politically motivated decisions have struck down a lot of progressive legislation. Justices have very regularly 'failed to defer to the decisions of elected branches, repeatedly betrayed a doctrine of strict textualism or Framers' "original intent", have not even pretended to defer to case precedent, refused to conform to jurisdictional limitations on the Court's power, spontaneously invented new constitutional rights and theories, imposed continuing affirmative obligations on the other branches [of government], and used judicial power to accomplish partisan objectives. Each of these deployments of judicial activism collides with the right of the people to practice democratic self-government'. Raskin goes even further by arguing that the Court has subverted 'political principles and rights for which the people have been fighting during the past two centuries of civilizing struggle'. While Graglia and Raskin may - and certainly do - disagree on specifics, the general tenor of their conclusions seems remarkably - taking into account their fundamental political differences - similar, if in fact not identical.

\section{I.}

It is my contention that the perception of the Supreme Court as an undemocratic body is generally mistaken. The critics of judicial activism make several incorrect assumptions and disregard important political and legal factors. First, they misunderstand the very nature and basic principles of a constitutional democracy. Second, they tend to ignore the role played by constitutions in general and the American Constitution in particular in social

\footnotetext{
${ }^{5}$ Lino A Graglia, 'Constitutional Law Without the Constitution: The Supreme Court's Remaking of America' in Robert H Bork (ed), A Country I Do Not Recognize: the Legal Assault on American Values (Hoover Institution Press 2005) 1-5; $<$ http://media.hoover.org $>$ accessed on 15.02.2010

${ }^{6}$ Jamin B Raskin, Overruling Democracy: the Supreme Court vs. the American People (Routledge 2003) 2-11.
} 
reality, effectively forgetting the reasons for the latter's hallowed place in the United States national psyche. Third, they ignore the presence of political factors (and even partisan calculations) in the process of appointments to the U.S. Supreme Court. Fourth, they misconceive the realities of the process of legal reasoning and of Constitutional interpretation. Fifth, they underestimate or even fail to recognize the influence of public opinion on the basic trends of judicial decision-making. In my opinion the debate on the questions of judicial activism, judicial restraint, and democratic legitimacy of constitutional courts is usually pointless and leads us astray. The proper subject of inquiry into judicial decisions should be whether they are correct (obviously from a legal, not political or ideological, point of view), and not whether they conform to some imprecise notions of allegedly democratic judicial restraint ${ }^{7}$. Let me be clear that I am not trying to prove too much. Certain decisions of the Supreme Court can more or less accurately be described as 'activist', but only if and only because they are legally wrong (e.g. they are examples of patently clear lawmaking, they misinterpret Constitutional clauses or they ignore earlier precedents without expressly overruling them). In other words, a decision is not wrong because it is an example of activism, but rather it may be an example of activism because it is wrong ${ }^{8}$. To reverse this order is to put the cart before the horse and to concentrate on bogeymen (like 'undemocratic Court', 'tyranny of judges', 'judicial oligarchy', 'pernicious activism', etc.) which may be an advantageous endeavor for politicians but not for legal scholars. In any case let us carefully consider the five arguments given above one by one.

A.

The first point is so glaringly obvious it feels almost embarrassing to be forced to make it. The detractors of the Supreme Court tend to perceive a situation in which Justices, during the process of constitutional adjudication, decide to invalidate certain legislation which enjoys overwhelming and widespread popular support, as somewhat problematic. It simply is not, from both a theoretical and practical standpoint. First and foremost, critics of activism seem to conveniently forget that the Constitution also is an emanation of the people's will. Provided the document is interpreted correctly, it is quite absurd to maintain that any decision the U.S. Supreme Court may have reached thwarts some fundamental democratic principles. Even if we have nearly unanimous popular support for certain measure, and only five Justices out of the whole society consider it constitutionally inadmissible and act accordingly, their actions should not be seen as undemocratic (assuming, again, that their interpretation is correct). The purported existence of a national consensus on any issue of public interest should be treated as absolutely irrelevant to judicial deliberations. Any majority (and particularly a transient one) may - and often does - desire

\footnotetext{
${ }^{7}$ For a different viewpoint see e.g. William P Marshall, 'Conservatives and the Seven Sins of Judicial Activism' (2002) 73 University of Colorado Law Review 1217 (footnote 3).

${ }^{8}$ It may even be convincingly argued that every incorrect decision is an activist one since in such case the Court escapes its clear legal obligation to properly determine the constitutionality of certain legislation. As far as democratic principles are concerned, I fail to discern any significant moral, legal or political difference between the incorrect upholding of an unconstitutional regulation and the incorrect invalidation of a constitutional one.
} 
unconstitutional solutions, and it is a constitutional tribunal's legal obligation to prevent it from reaching its goal. That is the whole point of having any sort of judicial review. Putting it a bit differently, countering majoritarian impulses in the name of a constitution is not per se an undemocratic activity; while the right of constitutional courts to have 'a last word" ${ }^{9}$ in matters of constitutional adjudication can be - and sometimes is - abused, we ought to remember that abusus non tollit usum; 'counter-majoritarian' difficulty" 10 , though undoubtedly real, is not a 'counter-democratic difficulty'. That is why, for instance, the U.S. Supreme Court was absolutely right when it summarily refused to reconsider its earlier decision which protected expressive rights of flag desecrators only because a significant majority of Americans found flag profanation reprehensible and wanted it criminalized (which is what the government would have the Court do $)^{11}$. Notwithstanding the merits of the original decision ${ }^{12}$ (and there is, in my assessment, plenty to argue about), the Court properly recognized public sentiment as an immaterial factor. Jeremy A. Waldron may be substantially correct in saying that 'in order to provide a democratic justification for the judges' prevailing' over the voting powers of the people's representatives, 'one has to show not only that they have democratic credentials but that they have a better democratic claim than that asserted in the legislative action in question ${ }^{\prime 13}$ (though weaker democraticness should not be automatically equated with undemocratic-ness; it is a continuum, not a dichotomy). Nevertheless, can we imagine a stronger democratic legitimacy than the one inferred more or less directly from constitutions themselves and applied in order to prevent transient majorities from violating (arguendo) the highest law of the land?

Furthermore, the opponents of activism often seem to display a tendency to identify democracy primarily with a procedural system of majority rule. This is a typical pars pro toto mistake which causes them to misconceive the very nature of American political model. To some degree it is generally reasonable to maintain that vigorous judicial review 'stands in contradistinction to majoritarian democracy [...] If nine unelected justices [...] can overturn the product of the majoritarian branches of government, then they defeat or curb the democratic will. A majoritarian democracy cannot tolerate unelected and unaccountable officials making major changes in the law, and sometimes overturning the law and replacing it with what they think the law should be. This usurps the purpose of the majoritarian branches of government and leads to judicial tyranny' ${ }^{14}$. However, to conclude that

\footnotetext{
9 Wojciech Sadurski, 'Spór o ostatnie stowo: sądownictwo konstytucyjne a demokracja przedstawicielska' (1998) 2 Civitas: Studia z Filozofii Polityki 96.

10 Alexander M Bickel, The Least Dangerous Branch: the Supreme Court at the Bar of Politics (Bobbs-Merrill 1962) 16.

${ }^{11}$ United States v Eichman (1990) 496 US 310, 319.

${ }^{12}$ Texas $v$ Johnson (1989) 491 U S 397.

13 Jeremy A Waldron, 'Right-based Critique of Constitutional Rights' (1993) 13 Oxford Journal of Legal Studies 44.

${ }^{14}$ Robert J Lipkin, Constitutional Revolutions: Pragmatism and the Role of Judicial Review in American Constitutionalism (Duke University Press 2000) 232.
} 
straightforward and mostly exception-free rule of the majority lies at the core of democracy is to go wide of the mark. The political system of the United States (as well as almost all contemporary Western models of government) can be more accurately described as a constitutional democracy where the Constitution has been explicitly introduced - at least partly - in order to provide barriers against the unfettered pretensions and wishes of popular or legislative majorities. Being anti-majoritarian is not the same thing as being anti-democratic. The existence of a constitutional judge should rather be treated as an indispensable corollary, a constitutive criterion, of a true constitutional democracy which is not 'the power of the majority because there can exist an absolutism of "the several", or a legislative absolutism similar to the absolutism [...] "of one alone" or a royal absolutism"15.

Let me conclude on a slightly personal note by saying that it is quite disconcerting and baffling to a European ear to hear staunch conservatives (I certainly understand progressives like Raskin) denouncing judicial elitism and passionately extolling the virtues of unchecked majoritarian rule. While American and European historical experiences are obviously divergent, nobody ought to forget that tyranny of the majority is not just an abstract theoretical concept envisaged by social thinkers from Aristotle to de Tocqueville but a really serious danger against which we would do well to borrowing the famous phrase of Justice Oliver Wendell Holmes - remain eternally vigilant. While majorities are prone to committing the most atrocious mistakes, constitutional democracies' record in that regard - albeit by no means a perfect one - makes for far more pleasant reading. Finally, if a majority disapproves of judicial interpretations of the Constitution, it can always resort to amending the document. If it is true that the Supreme Court constantly blocks the popular will, the successful introduction of certain amendments aimed at ensuring that the majority's wishes are fulfilled should not be too difficult from a purely political perspective. Even the most 'activist' judiciary could not stop that.

B.

What is the purpose of having constitutions? It seems reasonable to assume that such documents are 'the foundation of all other legislation' 16 and - by extension - of a given sociopolitical system. Therefore, constitutions ought to (and usually do) state the most basic principles operating in a given society, determine the relations between different branches of government, enumerate the functions or tasks of political institutions and define the fundamental rights, freedoms, and duties of citizens. In other words, constitutions provide a general outline of political and legal systems. While it is certainly correct to say that the main body of the U.S. Constitution focuses primarily on structural issues, contains 'precious few direct references to the protection of individual rights' and is first and foremost 'devoted to the implementation of an intricate and innovative political theory - a constitutionally limited, federally structured, representative democracy', it nevertheless cannot be denied that the 'political structure adopted in the

\footnotetext{
${ }^{15}$ Dominique Rousseau, 'The Constitutional Judge: Master or Slave of the Constitution?' in Michel Rosenfeld (ed), Constitutionalism, Identity, Difference, and Legitimacy (Duke University Press 1994) 276.

${ }^{16}$ Jean Blondel, Comparing Political Systems (Praeger Publishers 1972) 171.
} 
Constitution was designed simultaneously to preserve individual liberty and to avoid tyranny $[\ldots]$ political structure and constitutional rights (should be) viewed as necessary but insufficient parts of a symbiotic, organic whole ${ }^{17}$ (an observation which gained even more potency when the Bill of Rights came into effect). Obviously constitutions usually leave legislative bodies a lot of room to maneuver in order to enable them to act in accordance with the current majority's preferences. Because of these conflicting factors, there exists an observable tension between the foundational role played by constitutions and the need for giving a certain leeway to legislatures; usually some delicate balance has to be struck. However, proponents of judicial restraint insist on shifting this balance firmly in one direction, which would have the unfortunate and maybe unforeseen consequence of rendering constitutions largely toothless and meaningless. Such a development would be particularly troublesome particularly in the American context. If we accept the position that the United States Constitution precludes - to borrow Graglia's words - very few public policy choices, we necessarily make the document essentially irrelevant with respect to the major controversies of our time. Let us take the Free Speech Clause as an illustrative example. The provision can either be interpreted narrowly as, for instance, a rule prohibiting only prior restraint ${ }^{18}$ or protecting only expressly political speech ${ }^{19}$, or expansively as a means of guaranteeing everyone a general freedom of expression (as the Supreme Court has done for many decades). Let us assume that both interpretations are substantially correct, ${ }^{20}$ i.e. that they both can be justified in light of some comprehensive theory of judicial reasoning. Which construction should be adopted by the U.S. Supreme Court? Opponents of activism would of course unanimously prefer the former one. It obviously follows that - from this perspective - such issues as, for example, governmental control over hate speech, entertainment, symbolic speech. music etc. are not - as a general rule - covered (or at least protected) by the First Amendment. To put it in different terms, the Constitution is supposedly silent on the subject of potential criminalization of non-verbal expression of ideas, of publishing immoral literary works, of showing stupefying motion pictures or of playing tasteless music. While it may be a sound and coherent intellectual proposition, does it really adequately reflect the place of the Constitution in American society? I believe that to take this view is to completely ignore the foundational function of constitutions. Moreover which is crucial as far as democracy is concerned - such a paradigm does not appear to correspond with the wishes of the United States' citizens. American reverence for Constitution - not only as a legal monument but as a living thing

\footnotetext{
${ }^{17}$ Martin H Redish, The Constitution as Political Structure (Oxford University Press 1995) 3-4.

${ }^{18}$ See Leonard W Levy, Legacy of Suppression: Freedom of Speech and Press in Early American History (Belknap Press 1960).

${ }^{19}$ See Robert H Bork, 'Neutral Principles and Some First Amendment Problems' (1971) 47 Indiana Law Journal 20.

${ }^{20}$ If advocates of judicial restraint deem the second option to be incorrect, they should criticize its supporters for being wrong, and not for being in favor of 'activism'.
} 
- is a rare, if not unique, phenomenon in comparison to other Western democracies. Would that fierce pride in this part of their national heritage survive if the Constitution became irrelevant and indifferent to controversial legislative efforts undertaken by a transient majority? If we turn the Constitution into little more than a government manual, I very much doubt it.

C.

To maintain that the Supreme Court is an undemocratic institution is to ignore both the theory and practice of Justices' selection. In its general form, the appointment process does not violate any democratic principle. It is worth pointing out that the Supreme Court is not a self-perpetuating entity which utilizes a method of co-optation; when a vacancy comes up, the remaining Justices play no official institutional role in filling the post. The Justices are also not elected by an undemocratic body, and obviously a place on the bench is not inherited. Those are classic undemocratic methods of selection. It cannot be overemphasized that a Justice's nomination and subsequent appointment comes as a direct consequence of actions undertaken by democratically elected representatives of the people. For sure, the democratic legitimacy of a Justice may not be as clear-cut and direct as it is in the case of Presidents and Senators; for sure, the fact that it is a lifetime appointment reduces the importance of democratic factors; for sure, the fact that a Justice - barring impeachment - cannot be removed from office diminishes his or her responsibility before the people. These all seem, however, to be merely quantitative rather than qualitative differences. To refuse to recognize the democratic origins of the Supreme Court is to subscribe to some radical version of democracy not taken out of 'The Federalist Papers' but rather directly from the writings of Jean Jacques Rousseau. Anyhow, nobody can seriously state that, say, the Secretary of State or Chairman of the Federal Reserve are chosen undemocratically even though they are not elected by popular vote. What is even more crucial to remember, political factors and calculations currently occupy a very prominent place during the process of a Justice's appointment. To put an ironic twist on the matter, it was Bork's failed nomination to the Supreme Court which for the first time put such issues front and center. As Norman Vieira and Leonard Gross point out, 'the Bork proceedings clearly established a firm precedent for ideological inquiries and for the rejection of judicial nominees, at least in some instances, on purely ideological grounds [...] there was scant precedent before the Bork hearings for rejecting Supreme Court nominees because of their judicial philosophy'21. So now, judicial philosophies, judicial decisions touching upon ideological issues, judicial political convictions and affiliations are all the subject of debates during the appointment process. In other words, the success or failure of a Justice's nomination is to a large degree dependent upon his political stance; democratically-elected Presidents and Senators enter these factors into the equation. We may either deplore or praise this development, but it is an objective reality. It seems even more significant that every citizen making an electoral decision can make reasonable assumptions concerning the kind of Justice their representative will support or oppose. You will get one type of

21 Norman Vieira, Leonard Gross, Supreme Court Appointments: Judge Bork and the Politicization of Senate Confirmations (Southern Illinois University Press 1998) 247. 
Justice if the decision is made by hard-core Republicans; you will get a totally different one if the choice rests in the hands of moderate Democrats. It is even often quite possible to identify a prospective Justice's position on specific issues like abortion, gun-owners rights, same-sex marriage etc. Therefore citizens are able to (and do) influence - consciously or unconsciously - the direction of constitutional jurisprudence. The fact that their political calculations may be mistaken and that sometimes unsatisfactory - from a certain voter's point of view - deals or compromises concerning judicial appointments get made does not render the Supreme Court an undemocratic institution. After all, are not the electorate's mistakes and political compromises simply an inevitable component or even the bread-and-butter of a democratic political system?

D.

Up to now I have attempted to demonstrate that the mechanism of judicial review (aggressive, if need be) and the existence of a Supreme Court unhesitant to defy the majority's wishes do not in themselves violate the basic principles of constitutional - if not majoritarian - democracy. The advocate of judicial restraint may nevertheless reply that the real problem with the Supreme Court's activism and its lack of democratic legitimacy lies in a method of judicial reasoning which has been often - and especially for the last fifty years - employed by clear majority of Justices. The argument would be that while the Court may not be per se an undemocratic institution, its modus operandi still infringes upon the people's rights. The main case in point would be Justices' willingness to authoritatively disqualify laws which cannot be described as evidently unconstitutional. The opponent of activism may claim that the Supreme Court by its expansive construction of many Constitutional clauses often crosses the threshold between law interpretation and lawmaking. I believe that in most situations such allegations are a direct result of misunderstanding the nature of judges' - and particularly constitutional judges' - activity. The old pragmatist dichotomy between 'law in books' and 'law in action' proves useful in explaining that statement. At the beginning every legal rule is nothing more than a text which - in order to become a part of sociopolitical reality - needs to be subjected to interpretation. Putting it in slightly different terms, the very process of understanding even the simplest legal rule includes a component of interpretation. While we may accept the old clara non sunt interpretanda maxim as correct, in the realm of law nothing - or at least hardly anything is so clear as not to require interpretation. Therefore, by necessity, law is always what judges (and other governmental bodies) say it is. Contrary to Montesquieu's position, judges are not merely passive beings; by definition they play a very active role in the lawmaking process. This observation is valid in all circumstances. Once again, this fact may be deplored or extolled, but it is a fact. It is especially important to note that - from a formal standpoint - judges do not have to remain within the parameters set by the legislator's interpretation. Just like a reader of Shakespeare may find in the bard's dramas a meaning unintended by their author, a judge may often discover in a legal 
text previously hidden senses which were unforeseen by a lawmaker. Justice Oliver Wendell Holmes - though hardly an objective voice - sums it up correctly: 'When we are dealing with words that also are a constitutive act, like the Constitution of the United States, we must realize that they have called into life a being the development of which could not have been foreseen completely by the most gifted of its begetters ${ }^{22}$. While this interpretive liberty is by no means absolute, a judge is usually left with a lot of breathing space. A constitutional judge's duty is to select the rules of interpretation that he or she will apply in the course of his or her decision-making. In the context of American jurisprudence, as I have already intimated, this choice is always an arbitrary and activist - though of course not unrestricted - one. As Richard A. Posner sagaciously remarks, 'you can adopt an interpretive rule that constitutional rights cannot be created by implication but must be stated expressly in the Constitution [...] But the choice of that interpretive rule is not something that can be derived by reasoning from agreed-upon premises $^{23}$. Therefore there is nothing inherently more 'activist' in selecting one set of interpretive rules over another, as Frederick Schauer's analogy plainly - though maybe unintentionally - demonstrates. In his opinion, constitutional language is like 'a black canvas'. 'We know when we have gone off the edge of the canvass even though the canvas itself gives us no guidance as to what to put on it ${ }^{24}$. If Justices stray beyond this canvas, we may with justification call their decision an 'activist' one. However, as long as Justices remain within the frame of the canvas, they discharge their Constitutional duties properly.

A critic of the Supreme Court may still insist that, by refusing to apply a particular set of interpretive rules (based on e.g. originalism or strict textualism), Justices behave in an activist and therefore undemocratic manner. Such an allegation misses the point and forces us to focus on a factor which is a side-issue at best, and a completely irrelevant distraction at worst. The proper inquiry should concentrate on two other fundamental things. The first basic question is whether the constitutional canvas is covered by a masterpiece or kitsch. The best results may be sometimes achieved by strictly sticking to the Framers' instructions on what and how to paint; sometimes by applying a contemporary understanding of particular clauses in the Constitution; sometimes by complying with the majority's wishes; sometimes by going right against the grain of current public opinion; sometimes by adhering to principles of strict textualism; sometimes by employing more dynamic methods of legal reasoning. In this respect, the end is far more important than the means of attaining it. The second issue which should be emphasized while evaluating the Supreme Court's jurisprudence is whether a picture gradually emerging on a certain canvas remains an internally coherent one. Once the Supreme Court agrees to apply particular interpretive rules to a particular Constitutional clause, it has to apply them consistently in every relevant case. Changing the interpretive rules depending on the essentially immaterial vagaries of a given case is incorrect (and can be described as 'activist'). Let us once again use the example of the allegedly undemocratic

\footnotetext{
${ }^{22}$ State of Missouri v Holland (1920) 252 US 416, 433.

${ }^{23}$ Richard A Posner, How Judges Think (Harvard University Press 2008) 104.

${ }^{24}$ Frederick Schauer, 'An Essay on Constitutional Language' (1982) 29 UCLA Law Review 828.
} 
flag desecration decisions. Once the Supreme Court accepted the position that the First Amendment protects at least some methods of non-verbal expression of ideas, it cannot blatantly ignore the fact that the definition of symbolic speech (there has to be an intent to convey a particularized message which in great likelihood will be understood by viewers ${ }^{25}$ ) encompasses expressive flag burning. This would be precisely the worst kind of activism. Therefore the fact that the flag-burning decisions were opposed by a significant majority of the American public has nothing to do with their democratic or undemocratic character.

E.

I admit that the fifth point is the most controversial one. I do not believe that the courts are as insular as opponents of activism portray them to be. To a large degree, judicial institutions - including the U.S. Supreme Court - are not immune to outside pressures and take into account sentiments exhibited by ordinary citizens. For sure, I do not intend to say that there are no tensions between judges and public opinion. We can observe evidence of such tensions almost every day. However, these conflicts often seem to be blown totally out of proportion by both media and politicians who naturally prefer to focus their attention on things that do not work or are headed in the wrong direction. Because of that, we are often inclined to neglect the fact that the courts and public opinion very often - from a long-term perspective remain in at least basic agreement. In other words, sooner or later the spirit of the times can usually find its way into many judicial decisions and opinions. Some specific examples will serve to illuminate my point. Forgetting about the merits of the legal reasoning applied in the following cases, let us start by contrasting a general sentiment expressed in the notorious Lochner decision $(1905)^{26}$ with ideological undertones clearly present in two later decisions, i.e. Nebbia $v$ New York $^{27}$ and Wickard v Filburn ${ }^{28}$. The former - which invalidated state regulation establishing a maximum number of working hours for employees working in bakeries and confectionaries - reads like an excerpt from a libertarian manifesto. Justice Peckham's opinion denounces in no uncertain terms - governmental paternalism, sets rigid limits on a state's police power, praises individual freedom and liberty of contract and criticizes unsubstantiated governmental claims to interfere with citizens' private lives. From a sociopolitical perspective, the Lochner decision is emblematic of the period of untamed capitalism, laissez-faire, individualism, self-sufficiency etc. It perfectly mirrors these commonly recognized values. Only twenty nine years later - in the Nebbia decision - the Supreme Court rules that it is within the constitutional power of a state to regulate prices of milk. Justice Roberts' opinion emphasizes that 'neither property rights nor contract rights are absolute; for government cannot exist if the citizen may at will use his

\footnotetext{
${ }^{25}$ See Spence v Washington (1974) 418 US 405, 411.

${ }^{26}$ Lochner $v$ People of State of New York (1905) 198 US 45.

27 (1934) 291 US 502.

28 (1942) 317 US 111.
} 
property to the detriment of his fellows, or exercise his freedom of contract to work them harm. Equally fundamental with the private right is that of the public to regulate it in the common interest'. Barely eight years later - in the Wickard decision - the Court goes even further and declares that the federal government is constitutionally allowed to set compulsory national marketing quotas with respect to agricultural products. It is rather obvious that these decisions are based on principles diametrically opposed to those adopted in the Lochner ruling. Nevertheless, they also reflect the spirit of times when the experience of the Great Depression and New Deal stimulated skepticism towards unrestrained capitalism and made people far more receptive to interventionist concepts. An analogous diagnosis can be made as far as the First Amendment jurisprudence is concerned. For comparative purposes, we can use on one hand the Chaplinsky ${ }^{29}$ and Beauharnais ${ }^{30}$ decisions, in which free speech claims were summarily and quite imperiously dismissed and punishment for relatively innocuous - at least by today's standards expression upheld, and on the other the Cohen decision in which the Supreme Court, following a careful and detailed examination of the question, declared that a citizen has a right to enter a courtroom wearing a t-shirt emblazoned with profanities ${ }^{31}$. These decisions also appear to be a reflection of social circumstances and changing public attitudes. While it is almost impossible to imagine that during the 1940s a majority of Justices would extend First Amendment protection to the pronouncement 'Fuck the draft', it is equally unthinkable that during the 1970s the Supreme Court would find no Constitutional problem with criminally punishing someone for uttering phrases like 'damned Fascist' or for complaining about the number of 'Negroes' in certain neighborhoods. Such decisions are more understandable if we place them within the existing social context. To sum up, significant doctrinal shifts in the general tendencies of the Supreme Court's jurisprudence can often be explained by looking at the broader social situation in which they occurred; Justices are by no means absolutely impervious to democratic public opinion. This regularity has been consistently present in the Supreme Court's history, transcending political and ideological factors. For example, with respect to judicial review of economic legislation a libertarian interpretive paradigm has been supplanted by an interventionist one, whereas in the free speech jurisprudence conservative positions have largely been replaced by libertarian ones. Let me stress once again that I am not attempting to overreach and to prove too much. In many specific cases the disagreement between the Supreme Court and citizenry is undoubtedly real and ferocious. Additionally, it should also be admitted that sometimes Justices prefer to lead or precede public opinion instead of following it. However - looking at the issue from a long-term perspective - I am inclined to perceive such occurrences more as exceptions than as a rule.

\footnotetext{
${ }^{29}$ Chaplinsky v State of New Hampshire (1942) 315 US 568.

${ }^{30}$ Beauharnais $v$ Illinois (1952) 343 US 250.

${ }^{31}$ Cohen $v$ California (1971) 403 US 15.
} 


\section{CONCLUSION}

Let me conclude on a personal note. Though fascinated by the United States Supreme Court as an institution, by no means can I be described as a blind fan of its rulings. The Court is obviously not an infallible entity. Sometimes its mistakes are of truly gigantic proportions, leaving later commentators scratching their heads in wonder while trying to comprehend how certain lapses were even possible. Nevertheless, the Court's errors, its misreading of the Constitution - i.e. of the will of the American people - its misinterpretation of law etc. do not render it an undemocratic institution; once again, abusus non tollit usum. Incorrect decisions of the Court ought to be seen as a consequence of a specific failure in legal reasoning, and not as a result of the evil and undemocratic machinations of some elitist clique intent on subverting, undermining and destroying the most fundamental principles of American democracy. 